\title{
The National Medicines Regulatory Authority Act: its birth, provisions and challenges
}

\author{
Jayakody $R L^{1}$ \\ Journal of the Ceylon College of Physicians, 2015, 46, 53-56
}

\section{Background}

Up until July 2015 the legal basis for medicines regulation in Sri Lanka was provided by the Cosmetics Devices and Drugs Act (CDD Act) No. 27 of 1980 and the CDD Regulations of 1984 and their subsequent amendments. While medicines regulation was taking place under the provisions of this Act, various interest groups were lobbying for reforms in the background, which came under the umbrella heading of 'implementing Bibile policies'. This process continued with varying interest in the 1990s. As a result, the Government of Sri Lanka produced a document titled "The National Medicinal Drug Policy - 2005". Cabinet approval was given in October 2007 to draft a new Act by repealing or amending the existing CDD Act to implement the National Medicinal Drug Policy (NMDP).

Accordingly, the Ministry of Health appointed the "Beligaswatte Committee" to prepare the draft Act. This committee was chaired by Dr. A.M.L. Beligaswatte (a former Director General of Health Services, (DGHS) and included several Directors of the Department of Health Services (DHS) including the Director, Medical Technology and Supplies (D, MT and S), a representative of the Attorney General's Department, a representative of the Legal Draftsman's Department, the Legal Officer of the Ministry of Health and Dr. Palitha Abeykoon (a former WHO consultant with experience in public health). The period 2007-2014 witnessed many changes. These included changes to the drafting committee, litigation by a patient interest group to expedite the drafting process and even a period where the draft act was lost! Operationalization of the NMDP became a major political issue. Different political parties used the issue of implementing Bibile policies into their political agenda. At this time, the then Minister of Health, Mr. Maithripala Sirisena took a personal interest and the process was expedited. The "Beligaswatte Committee draft Act" was finalized in

\footnotetext{
${ }^{1}$ Professor of Pharmacology, Faculty of Medicine, University of Colombo. Chairman, National Medicines Regulatory Authority, Sri Lanka.

E-mail: jayakodyrl@hotmail.com
}

the latter part of 2013. After perusal and corrections by the Legal Draftsman, it was presented to the Cabinet in March 2014. The Cabinet decided to refer it to a sub-committee. While the sub-committee was studying the draft, it was made public in the health web and a public seminar was conducted in June 2014 at the National Blood Bank Auditorium. This seminar was chaired by the then Minister of Health, Mr. Maithripala Sirisena. At this seminar, Professor R. L. Jayakody, the Professor of Pharmacology of the University of Colombo was requested to make a fair criticism of the draft Act. The expectation of the various interest groups was that the new Act should have a regulatory body that is independent from the DHS. Unfortunately the draft Act had the Drug Regulatory Authority well inside the DHS. This was highlighted by Professor Jayakody and several other deficiencies were pointed out by the participants of this seminar.

Thereafter the "Abeykoon Committee" was appointed by Mr. Maithripala Sirisena to produce a revised Act. This Committee had Dr. Palitha Abeykoon as the Chairman and included Professor R. L. Jayakody, Professor P. Galappatthy (a Professor in Pharmacology of the University of Colombo), Professor Tuley De Silva (UN consultant and university academic), Dr. Ananda Wijewickrama (Consultant Physician), Dr. Sriyani Dissanayake (Deputy Director, MT and S) and Mrs. A. R. Ahamed (Chief Legal Officer, MoH) as members. Retired Pharmacist Ms. Chinta Abayawardhana and pharmacist attached to the DMT and $\mathrm{S}$ Office Mr. Krisantha de Silva assisted the Committee.

This Committee studied the written submissions, consulted all stake holder groups and the local experts and after several sittings finalized their recommendations and produced a draft Act. This was handed over to the Minister in August 2014. The Legal Draftsman improved on the draft produced by the "Abeykoon Committee" and submitted a revised draft for the observations of the Ministry of Health. The "Abeykoon Committee" worked together with the Legal Draftsman to incorporate all of the relevant suggestions and the final draft of the English version of the Bill dated 02.02.2015 was submitted to the Parliament. 
During this period significant changes occurred in the political milieu and Mr. Maithripala Sirisena (along with Dr. Rajitha Senaratne and others) crossed over from the government to the opposite camp, and Mr. Maithripala Sirisena became the common candidate in the January 2015 Presidential Election. After him becoming the President of the Democratic Socialist Republic of Sri Lanka, the new Drugs Act got incorporated into the "100 day programme" put forward by him. During this period the Act went through the steps of an "Emergency Bill", perused by the Supreme Court, debated in the parliament and passed as an Act of Parliament in March, 2015. Hence the National Medicines Regulatory Authority Act No.5 was born. The enactment process was expedited through the efforts of Dr. Rajitha Senaratne, who functioned as the Minister of Health during this period.

Now that you are familiar with the events that led to the promulgation of the NMRA Act let us examine its contents. In the following sections some salient features of the Act are discussed.

\section{The National Medicines Regulatory Authority (NMRA)}

The Drug Regulatory Authority (DRA) which functioned under the previous CDD Act was part of the DHS. Under that Act the "Drugs Authority" was the DGHS and he had delegated the task of the Drugs Authority to the Director, MT and S. Under the NMRA Act the DRA is now called the National Medicines Regulatory Authority and it is located outside the DHS and will function as an independent authority. Here the word independent has two meanings. One is that it is independent of the DHS. The other is that it can function as an independent authority making its own decisions and control its activities. This new authority is answerable to the Minister of Health. Compared to the previous situation where one person (the D/MT and S) was responsible, now there is a 13 member Authority who is responsible for drug regulatory activities. The 13 members are also selected on defined criteria. The Chief Executive Officer (CEO) has to be a person having postgraduate qualifications in pharmacology, pharmacy or medicine. The NMRA will have various divisions. These include the medicines regulatory division, medical devices regulatory division, borderline products regulatory division, the laboratory, clinical trials regulatory division, inspectorate and enforcement division etc. Altogether 10 divisions are mentioned with possibility for more being made.

\section{Areas regulated}

In the repealed CDD Act, the areas regulated were medicines, medical devices and cosmetics. In the
NMRA Act the section on cosmetics has been deleted. This was done for 2 reasons.

(i) The mandate given to the group who drafted the Act was to cover the area of the NMDP. The NMDP does not have cosmetics in it. Hence cosmetics were not considered for inclusion.

(ii) The present DRA is depleted of human resource and it is unable to evaluate medicines and medical devices properly. If cosmetics are also included then the limited resources are going to get diluted further. Hence, this opportunity was used to uncouple cosmetics from the more important medicines and medical devices.

Although cosmetics were deleted, the NMRA Act has a group of products identified as borderline products. It is being increasingly recognized that there are lot of products that fall in the interphase between foods and medicines or between medicines and cosmetics. Most DRAs have found it difficult to classify them. Hence the NMRA Act has given recognition to this and decided to include borderline products under it for regulation. As the cosmetics are not covered in the NMRAAct, and the previous CDD Act which covered cosmetics is now repealed, presently there is no legal framework to cover cosmetics. This has caused difficulty to importers and exporters of cosmetics in getting their necessary certificates and licenses. This has been brought to the attention of the authorities. It is hoped that the authorities will bring legislation early to address this issue.

\section{Committee structure}

The decision making in the NMRAAct is delegated to several committees. The NMRA itself is a 13 member Committee. In addition there are committees responsible for evaluation of medicines (MEC), medical devices (MDEC), borderline products (BPEC), clinical trials (SCOCT) and for pricing (Pricing Committee). An appeals committee is included also. The composition of most of the committees is specified. However provision is given to co-opt members on a needed basis. In addition to the committees already mentioned there is a National Advisory Committee, whose function is to see to the implementation of the NMRA Act.

\section{Criteria of evaluation of products}

According to the repealed CDD Act medicines were evaluated on their efficacy, safety and quality. In the NMRAAct in addition to the above mentioned three standard criteria, the criteria of cost and need also have been included. It was thought that as a regulatory authority in the developing world it may want to consider 
cost and cost effectiveness in its deliberations when registering products. The provision for patients to import unregistered medicines for personal use is allowed in the Act.

\section{The laboratory}

Under the repealed CDD Act the National Drug Quality Assurance Laboratory (NDQAL) was located outside the DRA. This led to certain administrative difficulties and it was thought that the NMRA should have its own laboratory. In the NMRAAct the laboratory is named as the National Medicines Quality Assurance Laboratory (NMQAL) and it is placed within the NMRA as a division (the laboratory division). With this arrangement the NMRA will be able to make decisions about the laboratory directly.

\section{Pricing of medicines}

Making medicines affordable is an important dimension in the NMDP. For medicines to be affordable to the majority of the population they must be cheap. At the time the NMRA Act was drafted, it became apparent to the Committee that there was no effective law addressing price regulation of medicines in Sri Lanka. The Consumer Affairs Authority which is entrusted with price regulation does not have provision to influence the initial price of medicines. It can influence at the time of price revision only. Price revisions invariably lead to increase in the price. At the time of such revision the CAA can negotiate in reducing the requested increase in the price. The group who drafted the NMRA Act thought this arrangement as unsatisfactory. Hence under the NMRAAct provision is given to regulate the initial price and subsequent revisions of prices of medicines and medical devices.

\section{Regulation of pharmacies}

The NMRA has a separate pharmacy regulatory division. Each retail pharmacy should have at least one pharmacist who will be responsible for all operations related to medicines. As for dispensing practices one of the loopholes in the previous CDD Act has been plugged. Under the NMRA Act the dispensing has to be done by the pharmacist or by a pharmacy assistant under the direct supervision of the pharmacist.

\section{Prescribing}

As in the repealed CDD Act, doctors have to write the generic name of the medicine. Liberty is given for them to decide on a trade name of their choice. In the NMRA Act, in instances where a particular brand written in the prescription is not available in that pharmacy or is not affordable to the customer, the pharmacist may dispense any other generic brand of the specific medicine with the consent of the customer. Pharmacists are expected to inform the customer the brands and the prices of the specific medicine that they are buying which are stocked in that pharmacy. The object of these clauses is to involve the customers who are paying for their medicines in the decision making process.

\section{Local manufacture}

The NMRA has a separate division dedicated to handle issues pertaining to local manufacture of medicines. Clauses are there to assist the local manufacturers.

\section{Enforcement}

As in the repealed Act, the NMRA Act has sections dealing with authorized officers, offences and punishments.

As stated previously the NMRA Act was passed in March 2015. The government has to operationalize the Act. After discussion with the officials of the DHS, the Minister of Health, Dr. Rajitha Senaratne decided to operationalize the NMRA Act by gazetting the date of operation of the NMRA Act as July $1^{\text {st }} 2015$. This was done by joining the former D, MT and S Office and the NDQAL under one authority as the NMRA. Hence, the NMRA was born on July $1^{\text {st }} 2015$. The CDD Act got repealed on that day. A new Chairman, a CEO and the members have been appointed to the NMRA. The task of implementing the new NMRA Act will be the responsibility of this body.

\section{The challenges}

The challenges faced by the NMRA can be summarized as follows.

1. To establish itself as an Authority and draw up the Regulations to better operationalize the Act on a firm footing.

2. Recruit new staff to the NMRA and to function properly.

3. Get the committees functioning and get the medicines, medical devices and borderline products evaluated as per new criteria.

4. Get the Pricing Committee functioning and put in place procedures that make medicines and medical devices more affordable.

5. Improve the capacity of the NMQAL and put in place a system of routine monitoring of medicines in the market. 
6. Build a team which is able to deliver the services expected of the NMRA.

The NMRA will have to have short term, medium term and long term goals to achieve its objectives.

\section{References}

1. National Medicinal Drug Policy for Sri Lanka 2005, Ministry of Healthcare and Nutrition "Suwasiripaya" Colombo 10.

2. National Medicines Regulatory Authority-ABill, Parliament of the Democratic Socialist Republic of Sri Lanka Bill No.335 (03.03. 2015).
3. The National Medicines Regulatory Authority Act, No.5 of 2015. Parliament of the Democratic Socialist Republic of Sri Lanka. (19.03.2015)

4. Cosmetics Devices and Drugs Act No. 27 of 1980, Government of the Democratic Socialist Republic of Sri Lanka.

5. National Pharmaceutical Pricing Agency, India; The Gazette of India - Extraordinary Part II - Section 3 - Sub-Section (ii) Ministry of Chemicals and Fertilizers, Department of Chemicals and Petrochemicals, New Delhi (January 6, 1995).

6. Alexandre Dolgui, Jean-Marie Proth. Pricing strategies and models. Annual Reviews in Control 2010; 34: 101-10. 